AC 2012-5392: MULTI-INSTITUTIONAL TEAMING EXERCISES IN A GEOTECHNICAL ENGINEERING LABORATORY

Dr. James L. Hanson, California Polytechnic State University

Professor, Civil and Environmental Engineering Department, Cal Poly

Dr. David J. Elton, Auburn University

David J. Elton, Ph.D., S.M., P.E., is a professor, Civil Engineering Department, Auburn University, AL 36849 . 


\title{
Multi-institutional Teaming Exercises in a Geotechnical Engineering Laboratory
}

\begin{abstract}
A teaching methodology was developed incorporating teaming exercises that involved students from two universities. Students were assigned to groups containing members from both universities to complete laboratory assignments. Activities were established for meaningful and entertaining introductions between the individual team members prior to technical interactions. Assignments were developed to require sharing of data and collaborations amongst all team members, with special focus on inter-university collaborations and communications. Detailed electronic communications of the teams were evaluated for assessment of project success. In addition, surveys were conducted and focus group discussions (facilitated by an external assessment coordinator) were undertaken after the experiences to provide depth to the assessment program. This paper provides an overview of the activities, assessment of activities, suggestions for implementation, and overall challenges and opportunities with this method. In addition, the teaching and learning activities are placed in context of a larger project incorporating unconventional learning styles in the same course.
\end{abstract}

\section{Introduction and Background}

A project is underway to investigate the development of teaching and learning materials that incorporate unconventional learning styles and new electronic technologies for communication in an undergraduate introductory geotechnical engineering laboratory course. The project represents a collaboration between two U.S. universities for this collaboration: California Polytechnic State University termed Cal Poly (predominantly undergraduate institution) and Auburn University termed Auburn (Tier 1 research institution).

This paper provides progress on this extensive investigation including a description of new activities that have been conducted between the university partners, specifically in relation to multi-institutional teaming exercises. The paper includes a description of the exercises, assessment of the methodology, and suggestions for successful adoption of similar efforts.

Other efforts in inter-university teaming have been reported (e.g., ${ }^{1,2,3}$ ), including limited experiences in engineering. Such teaming exercises have high potential for training students at functioning in an increasingly distance-based workplace.

\section{Multi-Institutional Teaming Exercises}

Two laboratory sessions were developed for student teams that included members from both universities. The activities were conducted in both Spring 2011 and Fall 2011. The 
activities included a grain size distribution laboratory and a shear strength laboratory. Teams were assigned by the instructors to include 2 or 3 students from each university. The instructors were sensitive to (and avoided) providing communication details (e.g., phone numbers) publicly to the entire class. Students were required to submit a joint report to instructors at both universities at the end of the exercise. Instructors at both universities graded the laboratory reports. Students were aware that evaluation from an external instructor could affect their grade. Activities were established (i.e., icebreaker activities) for meaningful and entertaining introductions between the individual team members prior to technical interactions.

The intent of the icebreaker activities was to introduce a level of familiarity between team members that did not have the ability to meet in person. The icebreaker exercises included some geotechnical engineering content and the performance on these exercises was included in the scope of materials being graded for the assignment. An elaborate information-based treasure hunt (in equation format) was used to promote sharing of technical and entertaining informational content between the universities. The facts and figures used for the exercise included some technical content and some related to local flavor at each university campus and region. An example of the equations and variables used is presented in Figure 1. The equation format of the exercise simplified grading.

A second icebreaker activity that was conducted required students to take a photograph of a geologic or geotechnical engineering feature and share the photograph and brief description with their team members at the partner university. This permitted students to share personal experiences and hobbies in their selection of featured sites and associated descriptions.

For the grain size distribution laboratory, students at each university determined the grain size distribution of a sandy soil. Different soils were tested at each university. The assignment involved calculating the mixture ratios for the two soils (one from each university) to prepare a mixture that would function as an earthen filter for a related hydraulic application. The problem statement was established to require that both soils be incorporated into the filter material to provide an effective solution. This problem format demanded that students from each university contact their team members from the partner university for sharing of data and discussing their approach to designing a filter.

For the shear strength laboratory, a bearing capacity analysis was required for the assignment. Soil conditions were evaluated at each university and analysis of foundation capacity was conducted. For one term, the same soil was tested at each laboratory using different test methods and for the second term, different soils were tested at the partner universities. A problem statement was developed that required comparisons between the reported soil strengths and foundation capacities. 
Group \# 1: $L L-\left(N_{C N}+L_{h}\right)+\frac{M}{N_{d s}}-\frac{S_{200} N_{60}}{\left(Y_{C P}-Y_{A U}\right)} \sqrt{L_{B G A}-N_{p t}}$

Group \# 2: $L L-D_{t h}+\frac{M}{N_{d s}} \sqrt{N_{I N O}-N_{W H}}-\frac{S_{200} N_{60}}{\left(f_{C P}-f_{A U}\right)^{-1}}$

Group \# 3: $L L-\left(N_{r}-N_{f b}\right)+\frac{M}{N_{d s}} \sqrt{N_{C N}+L_{h}}-\frac{S_{200} N_{60}}{D_{t h}}$

Group \# 4: $L L-\left(Y_{C P}-Y_{A U}\right)+\frac{M}{N_{d s}}\left[\frac{S_{200} N_{60}}{D_{t h}\left(f_{C P}-f_{A U}\right)^{-1}}\right]$

Group \# 5: $L L-\left(L_{B G A}-N_{p t}\right)-\frac{M}{N_{d s}}-\left(N_{r}+N_{f b}\right) \frac{S_{200} N_{60}}{N_{I N O}-N_{W H}}$

Group \# 6: $L L-\left(N_{C N}+L_{h}\right)-\frac{M}{N_{d s}}\left(S_{200} N_{60}\right)^{-1}-\left(f_{C P}-f_{A U}\right)^{-1}-\left(L_{B G A}-N_{p t}\right)$

Group \# 7: $\left(Y_{C P}-Y_{A U}\right)+\frac{M}{N_{d s}}+\frac{S_{200} N_{60}}{\left(N_{N O}-N_{W H}\right)} \sqrt{D_{t h}}-L L$

Group \# 8: $\frac{1}{2}\left(N_{C N}+L_{h}\right)-\frac{\left(N_{I N O}-N_{W H}\right)}{L L}-\frac{S_{200} N_{60}}{Y_{C P}-Y_{A U}}+\frac{M}{N_{d s}}$

\begin{tabular}{|c|c|}
\hline Variable & Description \\
\hline $\mathrm{D}_{\text {th. }}$ & $\begin{array}{l}\text { Difference in years between the years of the two universities' mascots } \\
\text { on the Chinese calendar }\end{array}$ \\
\hline$f_{\text {AL }}$ & FM Frequency of Auburn's campus radio station \\
\hline$f_{c e}$ & FM Frequency of Cal Poly's campus radio station \\
\hline LBGA & Length of San Luis Obispo's "stickiest" alley way, in m \\
\hline $\mathrm{Lb}_{\mathrm{a}}$ & $\begin{array}{l}\text { The letter on the hill of Cal Poly's campus is the ___ the letter in the } \\
\text { alphabet. }\end{array}$ \\
\hline LL & $\begin{array}{l}\text { The value of liquid limit that is used to distinguish between high } \\
\text { plasticity and low plasticity clay }\end{array}$ \\
\hline $\mathrm{M}$ & The Richter magnitude of the recent earthquake in Japan \\
\hline $\mathrm{N}_{60}$ & Number of openings per square inch on a \# 60 sieve \\
\hline $\mathrm{N}_{\mathrm{CN}}$ & Cam Newton's Jersey Number \\
\hline $\mathrm{N}_{\mathrm{d} \delta}$ & $\begin{array}{l}\text { Number of data points usually plotted in a direct shear test (check lab } \\
\text { book) }\end{array}$ \\
\hline $\mathrm{N}_{\mathrm{ft}}$ & Number of National football championships Auburn has won: \\
\hline NINO & Number of In-N-Out Burger restaurants in California \\
\hline $\mathrm{N}_{\text {pt. }}$ & Number of poisoned trees on Auburn's campus \\
\hline $\mathrm{N}_{\mathrm{r}}$ & $\begin{array}{l}\text { Number of National rodeo championships Cal Poly has won: (men and } \\
\text { women's teams) }\end{array}$ \\
\hline $\mathrm{N}_{W H}$ & Number of Waffle House restaurants in Alabama \\
\hline $\mathrm{S}_{200}$ & Size (in $\mathrm{mm}$ ) of the openings on a \#200 sieve \\
\hline $\mathrm{Y}_{\mathrm{AU}}$ & Year Auburn was founded \\
\hline
\end{tabular}

Figure 1. Examples of Information-based Treasure Hunt for Icebreaker Activity

Due to the university schedules being significantly out of phase (end of Spring Semester at Auburn) corresponded with beginning of Spring Quarter at Cal Poly), the method for shear strength determination for the sand was simplified at Cal Poly to using the angle of 
repose as it was too early in the term to conduct direct shear test in a meaningful manner. For the second experience (fall term), the classes at the different universities were in phase and both laboratories tested the shear strength of the soil using the direct shear test.

Coverage of bearing capacity is not part of the normal curriculum of the introductory geotechnical engineering class at Auburn or at Cal Poly. Inclusion of the topic in this project therefore expanded the technical content of the courses. A concise set of handouts was provided to students to facilitate completion of this relatively high level material.

The assignments included highly prescribed timeline of project deliverables to keep the group interactions active and on schedule. The required deliverables ranged from quite minor (e.g., documentation of confirmed planned meeting time for the group) to more significant (e.g., submission of draft report from one university to the other). A less detailed timeline was used for the first exercise in Fall 2011. The second interaction that same term reverted back to the highly prescribed timeline for collaboration, which produced more timely results.

Team communications were monitored closely for evaluation of the project activities. A publicly announced dedicated email account was established that was required to be copied for all email correspondence of the teams. This method consolidated all projectbased communications into an easily accessible and dedicated archive. In addition, students were required to log all team communications, specifically those that did not involve email. Furthermore, a Facebook page was established for the class in an attempt to enhance group interactions. The Facebook page was used for posting the local geotechnical photographs of the second icebreaker activity.

Assessment of project activities has been conducted using a) peer evaluation of student work, b) the Felder-Silverman Learning Styles Index, ${ }^{4}$ c) student surveys, d) focus group video conferences between students and an external assessment consultant, and e) graded analysis of student work products.

\section{Assessment of Activities}

\section{Student Performance}

The technical performance on the inter-university teaming exercises was comparable to work conducted in conventional team settings. Students had difficulty with collaborative activities when limited direction was provided. Greater success in increasing the quantity of communications in inter-university team members was obtained when highly detailed instructions and associated timeline of staged deliverables was available and required.

\section{Student Perceptions}

Student perceptions covered a broad range of perspectives. Overall, this team activity was deemed more difficult to complete than conventional within-class team assignments. In response to a specific assessment survey question related to inter-university teaming ("I learned something of value from working with students from another campus"), the mean 
score of the student ratings was 3.48 and 3.20 at Cal Poly and Auburn, respectively (where 1 corresponded to strongly disagree and 5 corresponded to strongly agree).

The primary mode for assessment was the use of focus groups facilitated by an external education assessment consultant. The focus groups were conducted as synchronous video conferences in small groups (3-5 students each) wherein the students were seated in a private room for the video conference. Observations from the students, including some quotations from students, are presented in Table 1. Explanatory notes are provided from the perspective of faculty/project administration.

\section{Table 1. Student Perceptions from Experience}

\begin{tabular}{|c|c|c|}
\hline Theme area & Student Perception & Notes \\
\hline $\begin{array}{l}\text { Academic } \\
\text { schedule }\end{array}$ & $\begin{array}{l}\text { Students reported that Auburn was well ahead of Cal } \\
\text { Poly in the content for the collaboration, that Auburn } \\
\text { had already covered the concepts in the course while } \\
\text { Cal Poly had not, and that this made it difficult to } \\
\text { collaborate. }\end{array}$ & $\begin{array}{l}\text { The difference was due to the } \\
\text { quarter versus semester } \\
\text { schedules }\end{array}$ \\
\hline \multirow[t]{6}{*}{$\begin{array}{l}\text { Access to } \\
\text { inter- } \\
\text { university } \\
\text { team members }\end{array}$} & $\begin{array}{l}\text { There was some frustration with differential group } \\
\text { participation, that some students did not participate } \\
\text { much at all until the end; that "some stepped up, some } \\
\text { didn't do much." }\end{array}$ & \\
\hline & $\begin{array}{l}\text { Multiple students reported learning that "Distance isn't } \\
\text { a problem," and that "I didn't realize that distance } \\
\text { wasn't really an issue." }\end{array}$ & \\
\hline & $\begin{array}{l}\text { Given the difficulty in establishing contact with } \\
\text { students from the partner university, the one-week } \\
\text { timeline for the project was challenging. This was } \\
\text { especially problematic given the time zone difference } \\
\text { between the universities. For example, one Auburn } \\
\text { student explained that he did not receive a response } \\
\text { from his partner until midnight ( } 10 \text { pm for Cal Poly) } \\
\text { the night before the project was due. }\end{array}$ & \\
\hline & $\begin{array}{l}\text { Some students found the time zone differences to be a } \\
\text { challenge, others found that "the time zone difference } \\
\text { wasn't too difficult to manage." }\end{array}$ & \\
\hline & $\begin{array}{l}\text { Difficulty in getting in touch with students from the } \\
\text { partner university was mentioned by most students. } \\
\text { Specifically, initiating contact in a timely manner via } \\
\text { Facebook was not effective given that many students } \\
\text { took several days to respond to "friend requests." }\end{array}$ & $\begin{array}{l}\text { Multiple platforms (e.g., email, } \\
\text { Skype, Facebook, phone) were } \\
\text { attempted. All have benefits } \\
\text { and drawbacks. }\end{array}$ \\
\hline & $\begin{array}{l}\text { We collaborated more and it was smoother. Having } 2 \\
\text { weeks to complete it was better. However, it was } \\
\text { difficult because one week was Thanksgiving break. } \\
\text { Everyone was scattered so it was difficult to get in } \\
\text { touch. }\end{array}$ & $\begin{array}{l}\text { Alignment of course content } \\
\text { and calendar required } \\
\text { conducting the project over the } \\
\text { holiday break }\end{array}$ \\
\hline \multirow{3}{*}{$\begin{array}{l}\text { General } \\
\text { Impressions }\end{array}$} & This was students first cross-class collaboration project & In any course \\
\hline & $\begin{array}{l}\text { In general, students found that it was a "better idea } \\
\text { than what played out" }\end{array}$ & $\begin{array}{l}\text { Student frustration was high on } \\
\text { the first trial in Fall } 2011 \text { due } \\
\text { to limited direction provided. }\end{array}$ \\
\hline & $\begin{array}{l}\text { Asked to compare to other labs, students found that } \\
\text { "it's hard to judge because this was the only lab where } \\
\text { we hadn't learned the curriculum yet." }\end{array}$ & $\begin{array}{l}\text { Comments from the group that } \\
\text { was behind the schedule in } \\
\text { terms of technical status of the }\end{array}$ \\
\hline
\end{tabular}




\begin{tabular}{|c|c|c|}
\hline & $\begin{array}{l}\text { Students thought the experience would have been } \\
\text { better if done later in the course }\end{array}$ & course. \\
\hline & $\begin{array}{l}\text { Students thought the experience was a helpful } \\
\text { introduction to real world engineering work }\end{array}$ & \\
\hline & $\begin{array}{l}\text { Students recommended that the experience start with a } \\
\text { whole-class interactive video between campuses to } \\
\text { introduce the project }\end{array}$ & $\begin{array}{l}\text { This method had been } \\
\text { integrated to other aspects of } \\
\text { the broader project when } \\
\text { schedules permitted }\end{array}$ \\
\hline & $\begin{array}{l}\text { Students also recommended setting interim } \\
\text { deliverables that would force interaction and early } \\
\text { collaboration. One student recommended "Set } \\
\text { deadlines for several day chunks and deliverables." }\end{array}$ & $\begin{array}{l}\text { Highly detailed assignment } \\
\text { with staged deadlines was } \\
\text { more successful }\end{array}$ \\
\hline & $\begin{array}{l}\text { Students recommended using interactive video to } \\
\text { watch the other group perform procedures, both to } \\
\text { inform the lab report and to force collaboration and } \\
\text { accountability. "Nothing we did required seeing each } \\
\text { other." "Create mandatory time to collaborate in small } \\
\text { groups via video... would force everyone to be there." }\end{array}$ & $\begin{array}{l}\text { Synchronous class-to-clas } \\
\text { video conferencing was used } \\
\text { for other aspects of the broader } \\
\text { project. Accountability was } \\
\text { assured through monitoring the } \\
\text { team communication log. }\end{array}$ \\
\hline $\begin{array}{l}\text { General } \\
\text { Impressions }\end{array}$ & $\begin{array}{l}\text { Students at both universities agreed that they had } \\
\text { difficulty understanding the instructions and purpose } \\
\text { of the project [this related to the abbreviated filter } \\
\text { design exercise]. }\end{array}$ & $\begin{array}{l}\text { For the students, the first } \\
\text { multi-institutional teaming } \\
\text { exercise was an unexpected } \\
\text { component of an otherwise } \\
\text { conventional laboratory } \\
\text { assignment }\end{array}$ \\
\hline & $\begin{array}{l}\text { Many students indicated they were not aware that } \\
\text { collaboration was a main goal of the project. }\end{array}$ & \\
\hline & $\begin{array}{l}\text { Although students expressed frustration with this } \\
\text { collaborative project, grades on these projects were } \\
\text { high (range: } 92-97) \text {. }\end{array}$ & \\
\hline & $\begin{array}{l}\text { It did not go smoothly. We had communication } \\
\text { problems and getting everything done on time. }\end{array}$ & \\
\hline & $\begin{array}{l}\text { Once we got a hold of our partners it worked out } \\
\text { smoothly. We had more specific deadlines so it went } \\
\text { more smoothly. }\end{array}$ & $\begin{array}{l}\text { Comments in comparison } \\
\text { between the } 2 \text { assignments in } \\
\text { Fall } 2011 .\end{array}$ \\
\hline & $\begin{array}{l}\text { We had an email thread going but it was difficult } \\
\text { because it was doing on during Thanksgiving break so } \\
\text { there was a 2-day lull between communications. But } \\
\text { there was more evidence of a combined report with } \\
\text { this one than the first one. }\end{array}$ & \\
\hline & $\begin{array}{l}\text { Give more time to complete the project, give } 2 \text { weeks. } \\
\text { There is no guarantee that communication will go } \\
\text { smoothly, so we need more time. }\end{array}$ & \\
\hline & $\begin{array}{l}\text { Having projects earlier in the semester where the load } \\
\text { isn't great from other classes. Without all the other } \\
\text { load it would make it easier. }\end{array}$ & \\
\hline & I liked having specific timelines. & \\
\hline & $\begin{array}{l}\text { Give contact information at the beginning of the } \\
\text { semester so we have time to establish contact. }\end{array}$ & $\begin{array}{l}\text { Publication of contact } \\
\text { information was deemed a } \\
\text { privacy concern and therefore } \\
\text { only within-team contact } \\
\text { information was provided. }\end{array}$ \\
\hline
\end{tabular}

Suggestions from students to improve the collaborative activities included:

$\circ$ Clearer guidelines and expectations. 
- Longer timeline.

- Not assigning the project during Thanksgiving break.

- Having a list of contact information provided so there is no delay in getting in touch with partners.

- Assigning the projects earlier in the semester so there is more time to get in touch with partners and fewer distractions with other course load.

- Providing specific details about the projects in the syllabus so students can plan ahead of time.

Faculty Perceptions

The logistics associated with inter-university teaming were significant. This project was conducted to experiment with this teaching method on specific assignments within a laboratory course. It is anticipated that student perception would improve considerably if this effort was scaled up to a more formal structure including a series of assignments over a longer period of time. A considerable effort went into formulating the bearing capacity assignment for Spring 2011 to gain the most pedagogical benefit from this activity. The response to this activity was generally favorable. An abbreviated interaction was conducted in early Fall 2011 (filter design) with limited icebreaker component to the experience. The lack of student response to team members' requests was problematic and it is believed that this negative perception about such teaming exercises pervaded through the Fall 2011 term (to also impact the perception on the second exercise, a repeat of the detailed bearing capacity assignment). The instructors observed some broad benefits of this teaching method including placing students in positions just outside conventional comfort zones for learning activities. The findings from the surveys and focus group discussions indicate that students are not being exposed to this sort of activity in other courses. The video-conference focus groups as a means for assessing the project has proven to be highly effective at capturing genuine student perceptions.

Those considering implementation of such exercises in their teaching should expect a significant impact on the demands for course preparation. As plans are developed to potentially integrate this teaching methodology into the curriculum, a close coordination between partnering classes should be pursued (schedule within the academic term as well as daily schedule of classes to permit synchronous interactions if possible). These exercises are more complex to implement than what would be expected. Highly detailed instructions and staged due dates, while seemingly micromanaging the multi-university teaming experiences, are highly recommended for success with implementation.

\section{Broader Context of Project}

The activities described herein are part of a broader project incorporating unconventional learning styles in geotechnical engineering education. Other project activities include inter-university video conferencing, production of films in lieu of conventional written laboratory reports, development of student-designed experiments to demonstrate principles of soil mechanics, development of student-produced video-based learning 
modules, synchronous video conferencing interactions between the laboratory classroom and practitioners (including some international practitioners), and inclusion of learningstyle specific components of laboratory reports (e.g., exclusively graphical, exclusively photographic, or exclusively audio-based content). Details of the broader aspects of the project, including further background on the formulation of exercises involving unconventional learning styles, are provided elsewhere $5,6,7,8,9$.

\section{Summary and Conclusions}

Multi-institutional teaming exercises have been incorporated into an introductory geotechnical laboratory at partner universities including a primarily undergraduate institution and a Tier 1 research university. Activities were undertaken over multiple terms and repeated during a single term. The inclusion of inter-university teaming promotes students to develop their interpersonal and communication skills and work in unconventional classroom settings. The activities were complicated by different schedules at the universities (semester versus quarter systems and the different dates and times of laboratory sessions), time zone difference, and variable level of participation among team members. The students were challenged with this format of assignment. The final technical work was at a similar level as to what is produced by within-class groups. Recommendations for success in incorporating inter-university teaming exercises include being highly specific in timeline of staged deliverables over the duration of an assignment, allowing sufficient time (at least 2 weeks) for collaborations to occur, and incorporating icebreaker activities to bring familiarity to groups that are unable to meet in person.

\section{Acknowledgments}

The assistance of Mr. Gary Welling, Mr. Gregory Olsen, Mr. Daniel Pitts, Mr. Samuel Wheeler, Mr. Kirk Vandersall, and Dr. Nazli Yesiller is acknowledged. This material is based on work supported by the National Science Foundation under Grant No. DUE0817570. Any opinions, findings, and conclusions or recommendations expressed in this material are those of the authors and do not necessarily reflect the views of the National Science Foundation.

\section{References}

1. Holland, M. P. (1998). "Collaborative technologies in inter-university instruction," Journal of the A merican Society for Information Science, Volume 47, Issue 11, 857-862.

2. Larsen, K. R. T. and McInerney, C. R. (2002). "Preparing to work in the virtual organization," Information \& Management, Vol. 39, Issue 6, 445-456.

3. Herrera, O. A., Alves, G. R., Fuller, D. and Aldunate, R. G. (2006). "Remote Lab Experiments: Opening Possibilities for Distance Learning in Engineering Fields," Education for the $21^{\text {st }}$ Century - Impact of ICT and Digital Resources, IFIP International Federation for Information Processing, Volume 210/2006, 321325 . 
4. Felder, Richard. (1988) Learning And Teaching Styles in Engineering Education.

Engr. Education, 78(7), 674-681.

5. Hanson, J. L., Elton, D. J., and Vandersall, K. (2011). "Incorporating Various Learning Styles in a Geotechnical Engineering Laboratory,” Proceedings 2011 A SEE Annual Conference, ASEE.

6. Pitts, D., Elton, D., and Hanson, J. L. (2011). "Use of Student-Created Videos to Enhance Undergraduate Soils Lab Learning," Proceedings GeoFrontiers 2011, ASCE.

7. Hanson, J. L., Elton, D. J., Welling, G., Pitts, D., and Butler, D. (2010). "Using Video Technology to Extend Learning Styles in a Geotechnical Engineering Laboratory," Proceedings 2010 A SEE A nnual Conference.

8. Hanson, J. L. (2009). "Using Video Technology to Enhance an Inter-University Collaboration for a Geotechnical Engineering Laboratory,” Proceedings 2009 A SEE Annual Conference.

9. Hanson, J. L., and Kuraoka, S. (2009). "Bringing International Practice to the Geotechnical Engineering Classroom Using Video-Conferencing," Proceedings of the $17^{\text {th }}$ International Conference on Soil Mechanics and Geotechnical Engineering, ISSMGE, Alexandria, Egypt. 